\title{
Variations of TSNA Levels in Tobaccos Upon Heating at Moderate Temperatures *
}

\author{
by \\ Serban C. Moldoveanu ${ }^{1}$, Marlene Adams ${ }^{1}$, and Frank K. St.Charles ${ }^{2}$ \\ 1 R.J. Reynolds Tobacco Co., Winston-Salem, NC, USA \\ 2 St.Charles Consultancy, Winston-Salem, NC, USA
}

\section{SUMMARY}

Tobacco-specific nitrosamines (TSNAs) including nitrosoanabasine (NAB), nitrosoanatabine (NAT), 4-(methylnitrosamino)-1-(3-pyridyl)-1-butanone (NNK), and nitrosonornicotine $(\mathrm{NNN})$ are naturally present at trace levels in tobacco. During tobacco processing, preparation of expanded tobacco, and when tobacco is used in heat-not-burn type cigarettes, the tobacco is exposed to different degrees of heat. Heating of tobacco has been reported in the literature to increase the level of TSNAs. Since the increase of TSNAs in heated tobacco is still not well understood, the present study evaluated TSNA levels in six types of tobacco as a function of moderate heat exposure. These tobaccos included: flue-cured lower stalk, flue-cured upper stalk (US), Burley lower stalk, Burley upper stalk (US), and two Oriental blends (Turkey, Greece, Bulgaria, Northern Republic Macedonia). Heating was performed in sealed glass tubes at oven temperatures of $100^{\circ} \mathrm{C}, 150^{\circ} \mathrm{C}, 200^{\circ} \mathrm{C}$, and $250{ }^{\circ} \mathrm{C}$ for time intervals of $2 \mathrm{~min}$ and $5 \mathrm{~min}$. The temperatures inside the glass tubes were lower than the targets and were monitored separately as a function of glass tube heating. The study showed no meaningful differences within tobacco type (by stalk position) but showed considerable differences in the levels of TSNAs between different tobaccos, with the Burley tobaccos having the highest levels, and the Orientals the lowest. For all tobacco types, TSNAs increase to some extent when temperature increases. For 2-min heating, the increase in TSNAs is relatively small up to about $200{ }^{\circ} \mathrm{C}$, but the levels almost double when the oven temperature increases to $250^{\circ} \mathrm{C}$. For 5 -min heating, the increase in TSNAs starts at about $150^{\circ} \mathrm{C}$ with a maximum at $200{ }^{\circ} \mathrm{C}$ which can reach more than double the initial TSNA level. Longer heating at $250{ }^{\circ} \mathrm{C}$ ( $5 \mathrm{~min}$ ) starts to cause TSNAs decomposition and the levels are reduced. [Beitr. Tabakforsch. Int. 29 (2020) 84-96]

\section{KEY WORDS:}

TSNAs; tobacco heating; moderate temperatures

\section{ZUSAMMENFASSUNG}

Tabakspezifische Nitrosamine (TSNA) einschließlich Nitrosoanabasin (NAB), Nitrosoanatabin (NAT), 4-(Methylnitrosamino)-1-(3-pyridyl)-1-butanon (NNK) und Nitrosonornikotin (NNN) kommen im Tabak natürlicherweise in Spuren vor. Während der Tabakverarbeitung, der Herstellung von expandiertem Tabak und wenn der Tabak in Tabakprodukten verwendet wird, bei denen er erhitzt und nicht verbrannt wird, ist er unterschiedlichen Hitzegraden ausgesetzt. In der Literatur wird berichtet, dass das Erhitzen von Tabak die TSNA-Konzentration erhöht. Da es noch keine hinreichenden Erkenntnisse zum Anstieg des TSNAGehalts in erhitztem Tabak gibt, wurde in der vorliegenden Studie die Konzentration an TSNA in Abhängigkeit von moderater Hitzeeinwirkung in sechs Tabaksorten untersucht. Diese Tabaksorten waren: Flue-cured Lower Stalk, Flue-cured Upper Stalk(USA), Burley Lower Stalk, Burley Upper Stalk (USA) sowie zwei Orienttabak-Mischungen (Türkei, Griechenland, Bulgarien, Republik Nordmazedonien). Das Erhitzen erfolgte in versiegelten Glasröhren 
bei Ofentemperaturen von $100{ }^{\circ} \mathrm{C}, 150{ }^{\circ} \mathrm{C}, 200{ }^{\circ} \mathrm{C}$ und $250{ }^{\circ} \mathrm{C}$ über einen Zeitraum von $2 \mathrm{~min}$ bzw. 5 min. Die Temperaturen in den Glasröhren waren niedriger als die Zieltemperaturen und wurden separat in Abhängigkeit von der Erwärmung der Glasröhre überwacht. Die Studie zeigte innerhalb einer Tabaksorte (bei verschiedenen Blattstufen) keine bedeutsamen Unterschiede, es ergaben sich jedoch beträchtliche Unterschiede bezüglich des TSNA-Gehalts bei verschiedenen Tabaken. Hierbei konnten in den BurleyTabaken die höchsten Konzentrationen und in den OrientTabaken die niedrigsten Konzentrationen nachgewiesen werden. Bei allen Tabaksorten steigt der TSNA-Gehalt zu einem gewissen Grad mit dem Temperaturanstieg. Bei einem zweiminütigen Erhitzen bleibt die TSNA-Konzentration bis zu einer Temperatur von $200{ }^{\circ} \mathrm{C}$ relativ niedrig. Sie verdoppelt sich jedoch beinahe, wenn die Ofentemperatur auf $250{ }^{\circ} \mathrm{C}$ ansteigt. Beim fünfminütigen Erhitzen beginnt sich die TSNA-Konzentration bei ca. $150{ }^{\circ} \mathrm{C}$ zu erhöhen und erreicht ihren Maximalwert bei einer Temperatur von $200^{\circ} \mathrm{C}$. Dieser kann mehr als das Doppelte des ursprünglichen TSNA-Gehalts betragen. Das längere Erhitzen bei $250{ }^{\circ} \mathrm{C}$ ( $\left.5 \mathrm{~min}\right)$ führt zu einer allmählichen Zersetzung der TSNA und damit zu geringeren Konzentrationen. [Beitr. Tabakforsch. Int. 29 (2020) 84-96]

\section{RESUME}

Les nitrosamines spécifiques du tabac (TSNA), y compris la nitrosoanabasine (NAB), la nitrosoanatabine (NAT), la 4-(méthylnitrosamino)-1-(3-pyridyl)-1-butanone (NNK) et la nitrosonornicotine ( $\mathrm{NNN}$ ) sont naturellement présentes, à l'état de trace, dans le tabac. Lors du traitement du tabac, de la préparation du tabac expansé et d'une utilisation dans des produits de tabac qui "ne brûlent pas mais chauffent", le tabac est exposé à des degrés variables de chaleur. La littérature indique que le chauffage du tabac augmente les niveaux des TSNA. Sachant que l'augmentation des TSNA dans le tabac chauffé demeurait encore mal comprise, la présente étude évalua les niveaux de TSNA dans six types de tabacs en fonction d'une exposition modérée à la chaleur. Les tabacs retenus pour l'analyse furent: La partie inférieure sur la tige de tabac blond, la partie supérieure sur la tige de tabac blond (USA), la partie inférieure sur la tige de tabac Burley, la partie supérieure sur la tige de tabac Burley (USA) ainsi que deux mélanges de tabac d'Orient (Turquie, Grèce, Bulgarie, Macédoine du Nord). Le chauffage fut effectué dans des tubes de verre scellés dans un four porté à des températures de $100^{\circ} \mathrm{C}, 150^{\circ} \mathrm{C}, 200^{\circ} \mathrm{C}$ et $250{ }^{\circ} \mathrm{C}$ durant des intervalles de 2 et 5 minutes. Les températures à l'intérieur des tubes de verre s'avérèrent inférieures aux valeurs-cibles et furent observées séparément en fonction du chauffage des tubes de verre. L'étude ne révéla aucune différence significative pour un même type de tabac (indépendamment de la portion de la tige) mais épingla des différences considérables entre les divers types de tabac eu égard aux niveaux de TSNA; en l'occurrence, les tabacs Burley présentèrent les niveaux les plus élevés tandis que les tabacs d'Orient livrèrent les niveaux les plus bas. Indépendamment du type de tabac, les TSNA augmentèrent, dans une certaine mesure, à chaque hausse de la température. Pour un temps de chauf- fage de 2 minutes, l'augmentation des TSNA fut relativement mineure jusqu'à une température d'environ $200{ }^{\circ} \mathrm{C}$ mais les niveaux se mirent à presque doubler quand la température du four atteignit $250{ }^{\circ} \mathrm{C}$. Pour un temps de chauffage de 5 minutes, la hausse des TSNA s'enclencha à une température approximative de $150^{\circ} \mathrm{C}$ pour atteindre un pic à $200{ }^{\circ} \mathrm{C}$ qui provoqua plus qu'un doublement $\mathrm{du}$ niveau initial des TSNA. Un chauffage prolongé à $250{ }^{\circ} \mathrm{C}$ ( 5 minutes) déclencha un phénomène de décomposition des TSNA dont les niveaux se mirent à chuter. [Beitr. Tabakforsch. Int. 29 (2020) 84-96]

\section{INTRODUCTION}

Tobacco-specific nitrosamines including nitrosoanabasine (NAB), nitrosoanatabine (NAT), 4-(methylnitrosamino)-1(3-pyridyl)-1-butanone (NNK), and nitrosonornicotine (NNN) are naturally present at trace levels in tobacco. These levels vary considerably depending on many factors such as the type of tobacco (flue-cured, Burley, Oriental), the location of tobacco production, the leaf position, the leaf processing procedure, the tobacco age, etc. The level of TSNAs in tobacco is of considerable interest since these compounds are listed among the harmful and potentially harmful constituents (HPHC) of tobacco products on which FOOD \& DRUG ADMINISTRATION (FDA) requires reporting (1). Also, NNK and NNN have been classified as human carcinogens (Class 1) by the INTERNATIONAL AGENCY FOR RESEARCH ON CANCER (IARC) (2). Tobacco heating has been reported to increase the level of TSNAs in tobacco $(3,4)$. In addition to the heating of tobacco behind the burning cone of a common burning cigarette, there are other instances when tobacco is heated, although at lower temperatures. Such cases include processing (e.g., drying), Burley toasting, preparation of expanded tobacco, as well as the use in "heat-not-burn" type cigarettes. Since the increase of TSNAs in heated tobacco is still not well understood, this was investigated in the present study. Tobacco-specific nitrosamines (TSNAs) can be analyzed by various methods that have been extensively reported in the literature (5-18). These methods were applied on tobacco, cigarette smoke, and several tobacco products such as moist snuff. An adaptation of one of these methods (18) has been used in the present study and was applied to TSNA analysis in tobaccos. The study and the selection of the temperature range in which the tobacco was heated $(100,150,200$, $250{ }^{\circ} \mathrm{C}$ ) intended to provide information for the process in heat-not-burn type cigarettes and other instances in which tobacco is subject to moderate temperatures.

\section{EXPERIMENTAL}

\subsection{Materials}

Several chemicals including ammonium acetate, ammonium formate, formic acid, and acetonitrile were obtained from Sigma/Aldrich (St. Louis, MO, USA). Nicotine, nitrosoanabasine (NAB), nitrosoanatabine (NAT), 4-(methylnitrosamino)-1-(3-pyridyl)-1-butanone (NNK), nitrosonornicotine $(\mathrm{NNN}), \mathrm{NAB}-\mathrm{d}_{4}, \mathrm{NAT}-\mathrm{d} 4, \quad \mathrm{NNK}-\mathrm{d}_{4}$ and 
NNN- $\mathrm{d}_{4}$ were obtained from Toronto Research Chemicals Inc. (TRC) (North York, ON, Canada). Pure water $(18.2 \mathrm{M} \Omega / \mathrm{cm})$ was obtained from a Barnstead water purification unit (Thermo Fisher Scientific, Waltham, MA, USA). The GC vials were $2 \mathrm{~mL}$ with screw top caps with septa. For filtration $0.45-\mu \mathrm{m}$ PVDF filters were used (Whatman Autovial, GE Healthcare, Little Chalfort, UK).

\subsection{Instrumentation}

The instruments used for the analysis consisted of an Agilent 1290 HPLC binary system with a binary pump, an autosampler with cooling capability, and a column thermostatted compartment. The HPLC chromatographic separation was achieved on a Luna ${ }^{\circledR} \quad 3 \mu \mathrm{m}$ C18 $150 \times 3 \mathrm{~mm}$ from Phenomenex (Torrance, CA, USA). The MS/MS system was an API-6500 triple quadrupole mass spectrometer (AB Sciex, Framingham, MA, USA). The LCMS/MS system was controlled using Analyst 1.6.2 software, and the peak integration was performed with MultiQuant 3.0.1 software. The heating was performed in a Thermoline Furnace 62700 (Thermo Fisher, Waltham, MA, USA). Tobacco moisture was measured with a halogen moisture analyzer HE53 (Mettler Toledo, Greifensee, Switzerland).

\subsection{TSNAs standards preparation}

An extraction solution of $100 \mathrm{mM}$ ammonium acetate in water was prepared by dissolving $7.7 \mathrm{~g}$ of ammonium acetate into $1 \mathrm{~L}$ of purified water. The standard solutions were prepared from a stock solution of $162.65 \mu \mathrm{g} / \mathrm{mL}$ $\mathrm{N}$-nitrosonornicotine ( $\mathrm{NNN}), 164.036 \mu \mathrm{g} / \mathrm{mL} N$ '-nitrosoanatabine (NAT), $41.508 \mu \mathrm{g} / \mathrm{mL} N$-nitrosoanabasine (NAB) and $161.10 \mu \mathrm{g} / \mathrm{mL}$ nicotine-derived nitrosamine ketone (NNK). Standard 1 was prepared by $1 / 1000$ dilution of the stock solution with the extraction solution and used to prepare Standards 2-7, $1000 \mu \mathrm{mL}$ each. To each $1 \mathrm{~mL}$ standard was added $20 \mu \mathrm{L}$ of the internal standard solution.

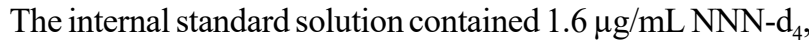

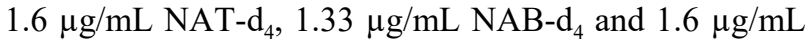
NNK- $d_{4}$. The concentration of internal standard (I.S.) in the final solution is indicated in Table 1.

Table 1. Concentrations of deuterated TSNAs in the samples containing internal standard solution.

\begin{tabular}{c|c|c|c}
\hline $\begin{array}{c}\mathrm{NNN}-\mathrm{d}_{4} \\
(\mathrm{ng} / \mathrm{mL})\end{array}$ & $\begin{array}{c}\mathrm{NAT-d_{4 }} \\
(\mathrm{ng} / \mathrm{mL})\end{array}$ & $\begin{array}{c}\mathrm{NAB}-\mathrm{d}_{4} \\
(\mathrm{ng} / \mathrm{mL})\end{array}$ & $\begin{array}{c}\mathrm{NNK- \textrm {d } _ { 4 }} \\
(\mathrm{ng} / \mathrm{mL})\end{array}$ \\
\hline 40.663 & 41.009 & 10.377 & 40.275 \\
\hline
\end{tabular}

The concentrations of the utilized standards are given in Table 2.

\subsection{Sample heat processing}

Heating of the tobacco was performed in sealed Pyrex glass tubes. This was done to avoid potential loss of material by evaporation when the tobacco was heated. Glass tube dimensions were $8 \mathrm{~mm}$ i.d. and a length of $15 \mathrm{~cm}$ with a
Table 2. Concentrations of TSNAs in the standard solutions.

\begin{tabular}{l|c|c|c|c}
\hline Standard & $\begin{array}{c}\mathrm{NNN} \\
(\mathrm{ng} / \mathrm{mL})\end{array}$ & $\begin{array}{c}\mathrm{NAT} \\
(\mathrm{ng} / \mathrm{mL})\end{array}$ & $\begin{array}{c}\mathrm{NAB} \\
(\mathrm{ng} / \mathrm{mL})\end{array}$ & $\begin{array}{c}\mathrm{NNK} \\
(\mathrm{ng} / \mathrm{mL})\end{array}$ \\
\hline 1 & 162.65 & 164.04 & 41.51 & 161.10 \\
2 & 81.33 & 82.02 & 20.75 & 80.55 \\
3 & 40.66 & 41.01 & 10.38 & 40.28 \\
4 & 20.33 & 20.50 & 5.19 & 20.14 \\
5 & 10.17 & 10.25 & 2.59 & 10.07 \\
6 & 5.08 & 5.13 & 1.30 & 5.03 \\
7 & 2.54 & 2.56 & 0.65 & 2.52 \\
\hline
\end{tabular}

1.0-mm wall thickness. About $600 \mathrm{mg}$ tobacco $( \pm 20 \mathrm{mg})$ were weighed into each tube. The tubes were sealed at one end and were subjected to a mild vacuum prior to sealing the other end. The purpose of applying a vacuum was to prevent the tubes from breaking when exposed to heat due to the expansion of gases in the tube. Figure 1 shows several sealed tubes containing powdered tobacco (Burley lower stalk) before heating.

Four different temperatures were used for heating the tubes: $100{ }^{\circ} \mathrm{C}, 150{ }^{\circ} \mathrm{C}, 200{ }^{\circ} \mathrm{C}$, and $250{ }^{\circ} \mathrm{C}$. Two time intervals were selected for heating: $2 \mathrm{~min}$ and $5 \mathrm{~min}$. The actual temperature of the tobacco was not measured during the experiments performed for TSNAs measurement. However, in a published study (3) the heating inside of a tobacco rod was evaluated, when exposed from exterior to $100{ }^{\circ} \mathrm{C}$ or $200{ }^{\circ} \mathrm{C}$. The study (3) indicated a delay in the temperature reached by the middle of a tobacco rod as compared to the applied external temperature. In the present study, an additional issue was that upon removing the glass tube with the tobacco from the oven, the cooling of the material was not instantaneous and it took 3-4 min for the tube to reach room temperature. For this reason, the temperature inside a sample (of Burley) was measured separately as a function of heating time. For this purpose a thermocouple was inserted into the sample during the heating of the glass tube containing the sample. At 5 min the heating was stopped by removing the glass tube from the oven and exposing it to room temperature. The temperature variation inside the sample is shown in Figure 2.

As indicated in Figure 2, the temperature to which the glass tube with sample is exposed is different from the actual temperature of the sample. Assuming a linear idealized temperature profile to which the tobacco is exposed, the temperature variation in the tobacco can be described by the following formula:

$$
\begin{gathered}
T(t)=T_{\text {init. }}+\mathrm{b}_{1} t\left(0<t<t_{\max }\right) \\
T(t)=T_{\text {init. }}+\mathrm{b}_{1} t_{\max }-\mathrm{b}_{2} t\left(t_{\max }<t<t_{\text {final }}\right)
\end{gathered}
$$

where $T(t)$ is the temperature of the sample as a function of time $t, T_{\text {init. }}$ is the initial temperature (about $22^{\circ} \mathrm{C}$ ), $t_{\max }$ is the length of time the sample is heated, $t_{\text {final }}$ is the time of cooling to room temperature, and $b_{1}$ and $b_{2}$ are heating and cooling rates, respectively. The fixed oven temperatures $100{ }^{\circ} \mathrm{C}, 150{ }^{\circ} \mathrm{C}, 200{ }^{\circ} \mathrm{C}$, and $250{ }^{\circ} \mathrm{C}$ for which the results are indicated in this study, are in fact described correctly by sample temperature variations as shown in Figure 2 and approximated by equation [1]. However, the linear approxi- 


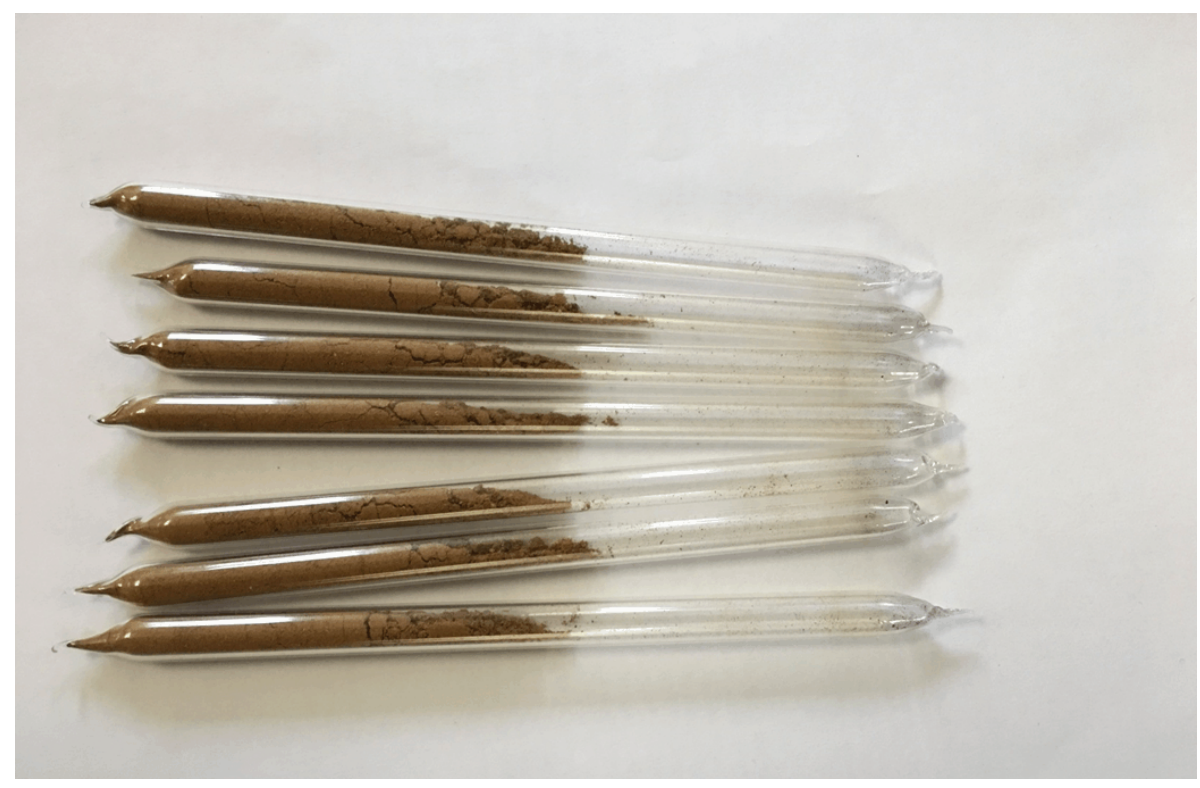

Figure 1. Sealed tubes containing powdered tobacco (Burley lower stalk) before heating.

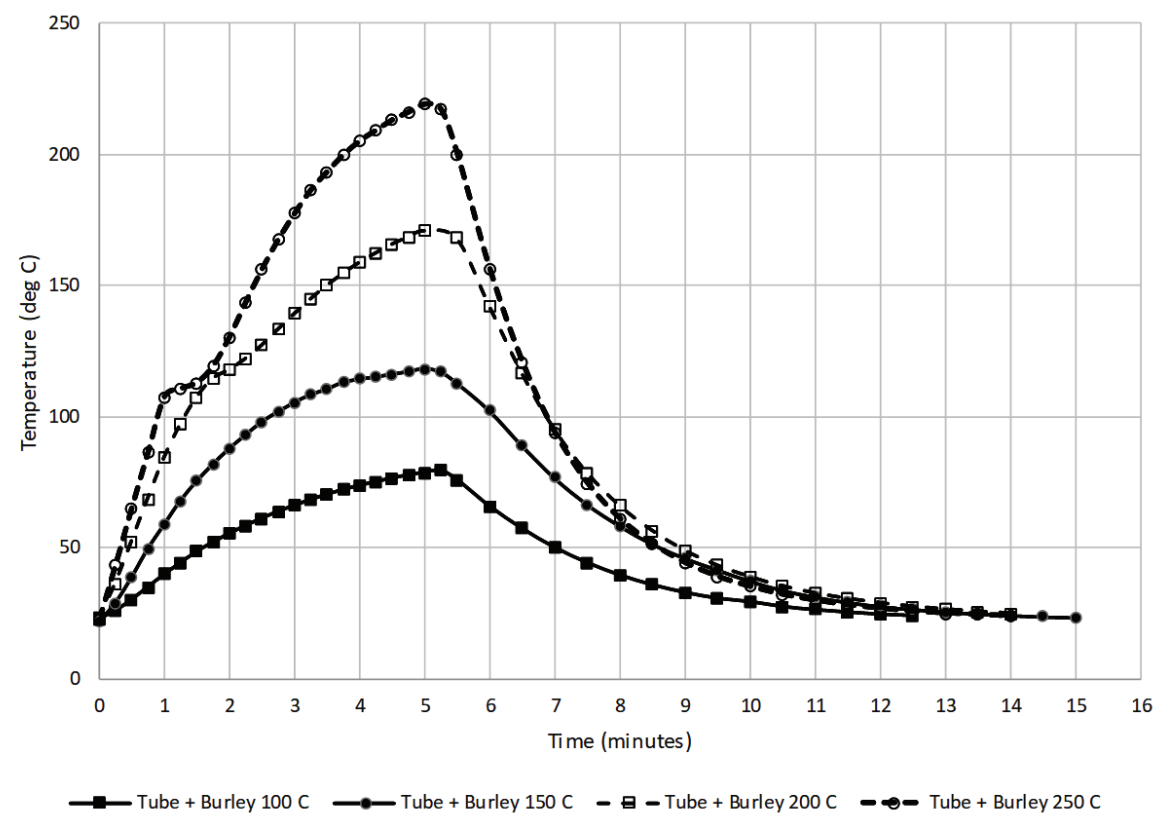

Figure 2. Temperature variation inside a tobacco sample placed in a glass tube as a function of heating time of the tube. Heating was stopped at $5 \mathrm{~min}$ and the samples were exposed to room temperature.

mation holds only for the first minute of heating. Afterwards the higher temperatures showed an endothermic leveling when passing $100^{\circ} \mathrm{C}$ and the rates for all temperatures decreased as the difference in temperature between the tobacco and the outside of the tube decreased. The initial slopes $\left({ }^{\circ} \mathrm{C} / \mathrm{s}\right)$ were proportional to the oven temperature and were equal to $[0.0076 \times$ oven temperature -0.494$]$ with an $R^{2}=0.999$. The initial rate of cooling was also linear and equal to $[-0.0062 \times$ oven temperature +0.433$]$ with an $R^{2}=0.939$. The cooling rate was slightly lower than the heating rate because the initial temperature difference was lower between the inside and the outside of the tube. The fixed temperatures of the oven, to which the glass tubes were exposed, were precisely controlled (within $1-2{ }^{\circ} \mathrm{C}$ ) while the true temperature of the samples was subject to variations depending on the exact mass of the glass tube, the mass of the tobacco sample, and on the distribution of the tobacco inside the glass tube during heating, all of which affected parameters $b_{1}$ and $b_{2}$. The use of sealed tubes as containers for the heated tobacco avoided potential loss of material by evaporation but at the same time did not allow a precise measurement of the temperature in the tobacco sample. This temperature can be inferred only by comparing the temperature of the heating of the glass tube with that inside the sample shown in the graph of Figure 2. 


\subsection{TSNA analysis}

Prior to the analysis, the moisture of the samples was measured using a halogen moisture analyzer. For the analysis, samples of $250 \pm 1.0 \mathrm{mg}$ of tobacco (as is) were weighed directly into $20-\mathrm{mL}$ scintillation vials. To each vial $10 \mathrm{~mL}$ of the extraction solution were added, then the vial was capped and placed into a shaker for $30 \mathrm{~min}$. The solution was then filtered through a syringe filter into a test tube. $1000 \mu \mathrm{L}$ of the filtered solution was transferred to a 2 -mL GC vial and $20 \mu \mathrm{L}$ of the TSNA internal standard was added to the sample.

The HPLC separation of TSNAs was performed using a gradient program. The mobile phase A was $100 \mathrm{mM}$ ammonium formate $\mathrm{pH} 4.9$ aqueous solution with $5 \%$ acetonitrile and mobile phase B was $0.2 \%$ formic acid in acetonitrile. The timetable for the gradient is shown in Table 3.

Table 3. Solvent gradient employed for the HPLC-MS/MS analysis of TSNAs.

\begin{tabular}{r|r|c|c}
\hline Time & $\% \mathrm{~A}$ & $\% \mathrm{~B}$ & $\begin{array}{c}\text { Flow rate } \\
(\mathrm{mL} / \mathrm{min})\end{array}$ \\
\hline 0.0 & 100.0 & 0.0 & 0.6 \\
1.7 & 100.0 & 0.0 & 0.6 \\
3.5 & 70.0 & 30.0 & 0.6 \\
4.5 & 60.0 & 40.0 & 0.6 \\
8.0 & 50.0 & 50.0 & 0.6 \\
10.0 & 100.0 & 0.0 & 0.6 \\
\hline
\end{tabular}

The parameters for the MS/MS detection included: curtain gas CUR $=20 \mathrm{~mL} / \mathrm{min}$, collision gas $\mathrm{CAD}=4 \mathrm{~mL} / \mathrm{min}$, ion spray voltage IS $=4500 \mathrm{~V}$, temperature $\mathrm{TEM}=500{ }^{\circ} \mathrm{C}$, ion source gas $1 \mathrm{GS} 1=40 \mathrm{~mL} / \mathrm{min}$, ion source gas $2 \mathrm{GS} 2=50 \mathrm{~mL} / \mathrm{min}$, entrance potential $\mathrm{EP}=10 \mathrm{~V}$, target scan time $0.11 \mathrm{~s}$, scheduled MRM detection window $40 \mathrm{~s}$. Other parameters including the analyzed ions are shown in Table 4.

Extracted ion chromatograms for the eight compounds measured in the study are shown in Figure 3 for a fluecured tobacco (upper stalk) heated at $200{ }^{\circ} \mathrm{C}$ for $5 \mathrm{~min}$. Both NNN and NNN-d4 show two peaks in the previously described separation conditions. Only the higher of the two peaks was used for the quantitation. Peak splitting for TSNAs can be attributed to the presence of a syn-anti iso- mers of the nitrosamine group.

For the quantitation of TSNAs, calibration curves were constructed by plotting the concentrations of the standard solutions as a function of the peak areas normalized to the area of the corresponding deuterated internal standards. All calibrations were linear and they were expressed using the formula:

$$
Y(\text { conc. })=a(\text { Std. Area/I.S. Area })+b
$$

Parameters $a$ and $b$ as well as correlation coefficient $R^{2}$ for the calibration lines are shown in Table 5.

The overall validation of the analytical method for the analysis of TSNAs has been previously reported (18) and no further validation has been performed for the method.

\section{RESULTS}

\subsection{Sample description}

The samples analyzed in this study are listed in Table 6, together with the measured moisture $\%$ total alkaloid level as well as the time intervals and temperatures to which they were exposed.

Some samples were processed in duplicate or even triplicate, and other samples were analyzed only once. The samples were randomly analyzed, and some duplicate or triplicate evaluations were made to verify the repeatability of the results. Once the sample was heated and extracted, the LC/MS/MS measurement was performed in duplicate.

\subsection{Average TSNA levels for the starting tobacco}

The results of average TSNA levels in $\mathrm{ng} / \mathrm{g}$ for the starting tobaccos (analyzed before starting the heating experiments) are shown in Table 7. All results are reported for the tobacco "as is," a conversion to "dry basis" being possible using the moisture data from Table 6.

As indicated in Table 7, the levels of TSNAs did not differ meaningfully within tobacco type (by stalk position), but among the various tobacco types they differed considerably. Burley tobaccos have a very high level of TSNAs even before heating. Significantly lower levels compared to the Burleys are present in flue-cured tobaccos. The lowest TSNA levels are present in the Oriental tobaccos.

Table 4. Other parameters for the MS/MS detection.

\begin{tabular}{|c|c|c|c|c|c|c|}
\hline Compound & Ion for Q1 & Ion for Q3 & Retention time (min) & $\mathrm{DP}^{1}(\mathrm{~V})$ & $\mathrm{CE}^{2}(\mathrm{~V})$ & $\mathrm{CXP}^{3}(\mathrm{~V})$ \\
\hline NNN & 178.1 & 148.1 & 4.73 & 30 & 15 & 9 \\
\hline NNN- $d_{4}$ & 182.1 & 152.1 & 4.70 & 30 & 16 & 9 \\
\hline NAT & 190.1 & 160.1 & 5.35 & 28 & 15.5 & 10 \\
\hline NAT- $d_{4}$ & 194.1 & 164.1 & 5.31 & 28 & 16 & 10 \\
\hline NAB & 192.1 & 162.1 & 5.40 & 26 & 18 & 11 \\
\hline NAB- $d_{4}$ & 196.1 & 166.1 & 5.37 & 26 & 17 & 10 \\
\hline NNK & 208.1 & 122.1 & 5.16 & 30 & 17.6 & 13 \\
\hline NNK-d ${ }_{4}$ & 212.1 & 126.1 & 5.15 & 30 & 16 & 12 \\
\hline
\end{tabular}

${ }^{1} \mathrm{DP}=$ Declustering potential; ${ }^{2} \mathrm{CE}=$ Collision energy; ${ }^{3} \mathrm{CXP}=$ Collision cell exit potential 

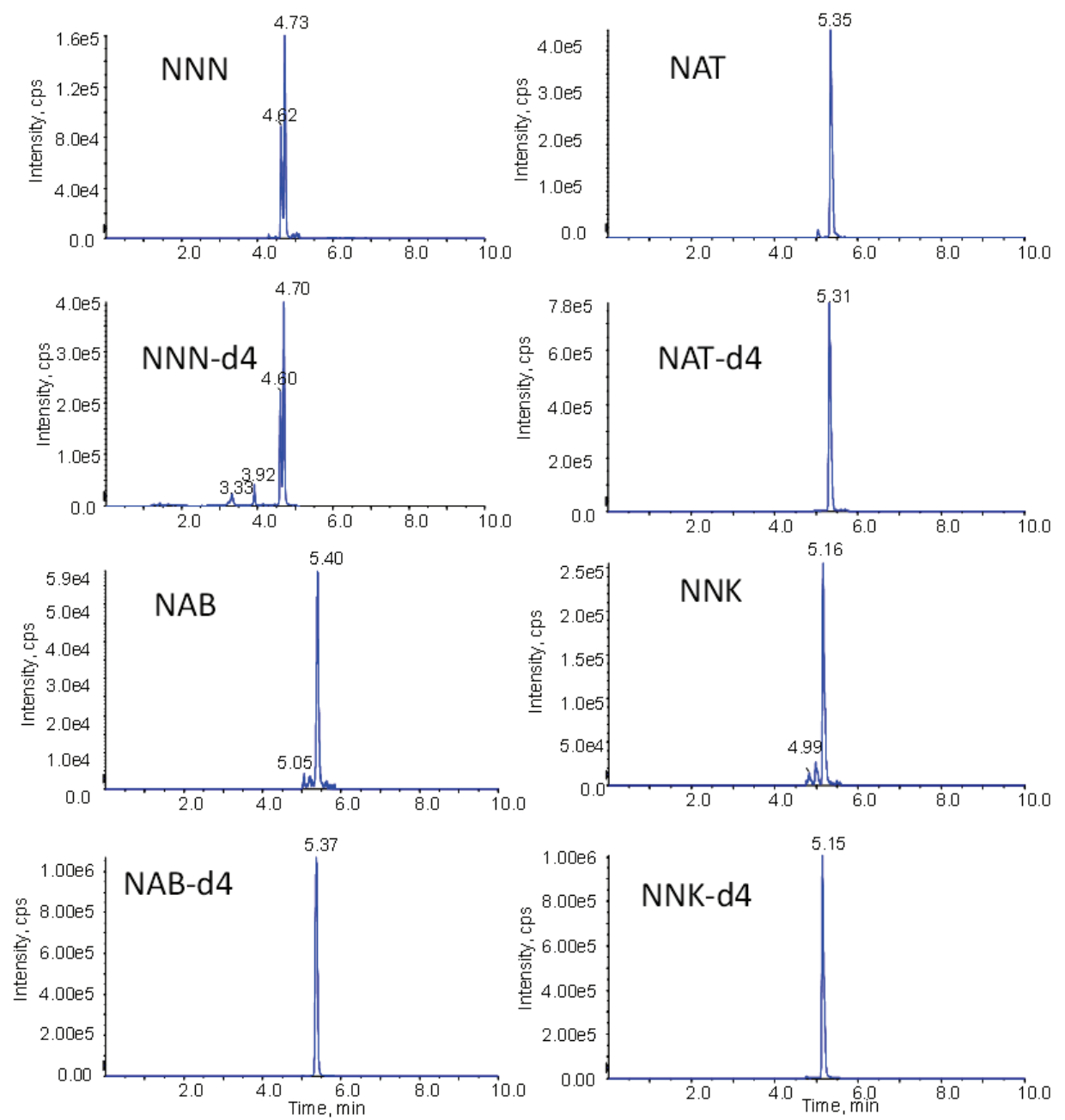

Figure 3. Extracted ion chromatograms for NNN, NAT, NAB and NNK and their $d_{4}$-labeled compounds measured for a flue-cured tobacco (upper stalk) heated at $200{ }^{\circ} \mathrm{C}$ for $5 \mathrm{~min}$.

Table 5. Parameters $a, b$ and $R^{2}$ for the MS/MS quantitation.

\begin{tabular}{l|c|c|c}
\hline Analyte & $\mathrm{a}$ & $\mathrm{b}$ & $\mathrm{R}^{2}$ \\
\hline NNN & 33.5151 & 0.1798 & 0.9997 \\
NAT & 40.8507 & 0.0479 & 0.9998 \\
NAB & 35.1528 & 0.0768 & 0.9992 \\
NNK & 35.7655 & 0.0889 & 0.9996 \\
\hline
\end{tabular}

Table 7. Initial TSNA levels in the tobacco samples in $\mathrm{ng} / \mathrm{g}$ (tobacco as is).

\begin{tabular}{l|r|r|r|r}
\hline $\begin{array}{l}\text { Sample } \\
\text { acronym }\end{array}$ & $\begin{array}{r}\text { NNN } \\
(\mathrm{ng} / \mathrm{g})\end{array}$ & $\begin{array}{c}\text { NAT } \\
(\mathrm{ng} / \mathrm{g})\end{array}$ & $\begin{array}{c}\text { NAB } \\
(\mathrm{ng} / \mathrm{g})\end{array}$ & $\begin{array}{r}\text { NNK } \\
(\mathrm{ng} / \mathrm{g})\end{array}$ \\
\hline FC-Lo & 365.2 & 566.5 & 33.2 & 283.1 \\
FC-Up & 354.1 & 458.3 & 32.6 & 227.4 \\
Bu-Lo & 4688.3 & 4616.8 & 199.7 & 861.0 \\
Bu-Up & 4780.3 & 4662.1 & 183.2 & 773.3 \\
Or (1) & 156.6 & 54.8 & 6.14 & 43.0 \\
Or (2) & 126.4 & 33.5 & 4.79 & 32.6 \\
\hline
\end{tabular}

Table 6. Tobacco samples, moisture (\%), alkaloid level (\%), and the conditions to which the samples were exposed.

\begin{tabular}{|c|c|c|c|c|c|c|c|c|c|}
\hline \multirow{2}{*}{$\begin{array}{l}\text { Sample } \\
\text { acronym }\end{array}$} & \multirow{2}{*}{$\begin{array}{l}\text { Tobacco description } \\
\text { Lower stalk flue-cured }\end{array}$} & \multirow{2}{*}{$\begin{array}{c}\begin{array}{c}\text { Moisture } \\
(\%)\end{array} \\
6.44\end{array}$} & \multirow{2}{*}{$\begin{array}{c}\begin{array}{c}\text { Total alkaloids } \\
(\%)\end{array} \\
2.07\end{array}$} & \multicolumn{4}{|c|}{$\begin{array}{l}\text { Temperatures } \\
\left({ }^{\circ} \mathrm{C}\right)\end{array}$} & \multicolumn{2}{|c|}{$\begin{array}{l}\text { Time of exposure } \\
\text { (min) }\end{array}$} \\
\hline & & & & 100 & 150 & 200 & 250 & 2 & 5 \\
\hline FC-Up & Upper stalk flue-cured & 6.71 & 2.85 & 100 & 150 & 200 & 250 & 2 & 5 \\
\hline Bu-Lo & Lower stalk Burley & 6.36 & 2.51 & 100 & 150 & 200 & 250 & 2 & 5 \\
\hline Bu-Up & Upper stalk Burley & 7.11 & 3.46 & 100 & 150 & 200 & 250 & 2 & 5 \\
\hline Or (1) & Oriental blend (1) & 6.64 & 1.13 & 100 & 150 & 200 & 250 & 2 & 5 \\
\hline Or (2) & Oriental blend (2) & 6.23 & 1.02 & 100 & 150 & 200 & 250 & 2 & 5 \\
\hline
\end{tabular}


Table 8. Variation of TSNAs in flue-cured tobaccos upon heating (in $\mathrm{ng} / \mathrm{g}$ ).

\begin{tabular}{|c|c|c|c|c|}
\hline \multirow{2}{*}{$\begin{array}{c}\text { Temperature } \\
\left({ }^{\circ} \mathrm{C}\right)\end{array}$} & \multicolumn{2}{|c|}{ Flue-cured lower stalk, FC-Lo } & \multicolumn{2}{|c|}{ Flue-cured upper stalk, FC-Up } \\
\hline & $2 \min$ & $5 \mathrm{~min}$ & $2 \min$ & $5 \mathrm{~min}$ \\
\hline \multicolumn{5}{|c|}{ NNN (ng/g) } \\
\hline 23 & $372.5 \pm 2.1$ & $372.5 \pm 2.1$ & $358.3 \pm 3.9$ & $358.3 \pm 3.9$ \\
\hline 23 & $357.9 \pm 0.5$ & $357.9 \pm 0.5$ & $342.9 \pm 1.7$ & $342.9 \pm 1.7$ \\
\hline 23 & - & - & $361.0 \pm 2.9$ & $361.0 \pm 2.9$ \\
\hline 100 & $397.9 \pm 6.9$ & $400.8 \pm 0.2$ & $378.9 \pm 9.1$ & $389.5 \pm 5.3$ \\
\hline 100 & - & - & $388.8 \pm 2.6$ & $380.5 \pm 3.5$ \\
\hline 150 & $420.5 \pm 1.7$ & $465.3 \pm 1.4$ & $392.7 \pm 10.4$ & $422.6 \pm 4.7$ \\
\hline 150 & - & - & $391.7 \pm 14.3$ & - \\
\hline 200 & $479.8 \pm 1.7$ & $697.4 \pm 5.2$ & $457.5 \pm 10.2$ & $540.5 \pm 9.3$ \\
\hline 200 & - & - & $461.3 \pm 4.7$ & $546.0 \pm 3.3$ \\
\hline 250 & $496.7 \pm 9.2$ & $109.1 \pm 0.4$ & $595.8 \pm 42.4$ & $102.4 \pm 0.6$ \\
\hline \multicolumn{5}{|c|}{ NAT (ng/g) } \\
\hline 23 & $566.7 \pm 7.2$ & $566.7 \pm 7.2$ & $469.1 \pm 4.7$ & $469.1 \pm 4.7$ \\
\hline 23 & $566.4 \pm 4.8$ & $566.4 \pm 4.8$ & $447.9 \pm 7.4$ & $447.9 \pm 7.4$ \\
\hline 23 & - & - & $457.9 \pm 2.1$ & $457.9 \pm 2.1$ \\
\hline 100 & $602.8 \pm 18.0$ & $645.0 \pm 4.6$ & $520.0 \pm 12.7$ & $492.6 \pm 1.0$ \\
\hline 100 & - & - & $517.5 \pm 22.5$ & $483.6 \pm 3.1$ \\
\hline 150 & $693.2 \pm 3.2$ & $836.3 \pm 10.9$ & $529.3 \pm 8.4$ & $618.3 \pm 1.6$ \\
\hline 150 & - & - & $520.9 \pm 4.1$ & - \\
\hline 200 & $909.8 \pm 5.0$ & $1366.4 \pm 5.6$ & $649.3 \pm 11.7$ & $871.2 \pm 1.7$ \\
\hline 200 & - & - & $657.5 \pm 1.4$ & $885.8 \pm 6.6$ \\
\hline 250 & $945.6 \pm 5.8$ & $17.1 \pm 0.9$ & $1039.2 \pm 30.6$ & $10.9 \pm 0.2$ \\
\hline \multicolumn{5}{|c|}{ NAB (ng/g) } \\
\hline 23 & $31.9 \pm 0.1$ & $31.9 \pm 0.1$ & $34.8 \pm 3.1$ & $34.8 \pm 3.1$ \\
\hline 23 & $34.5 \pm 0.2$ & $34.5 \pm 0.2$ & $30.4 \pm 0.2$ & $30.4 \pm 0.2$ \\
\hline 23 & - & - & $32.7 \pm 0.2$ & $32.7 \pm 0.2$ \\
\hline 100 & $40.3 \pm 0.5$ & $38.0 \pm 0.8$ & $36.5 \pm 0.5$ & $36.9 \pm 0.4$ \\
\hline 100 & - & - & $38.4 \pm 0.4$ & $37.1 \pm 0.5$ \\
\hline 150 & $39.6 \pm 0.2$ & $46.4 \pm 1.2$ & $37.0 \pm 0.2$ & $43.8 \pm 0.2$ \\
\hline 150 & - & - & $38.2 \pm 0.8$ & - \\
\hline 200 & $51.1 \pm 0.5$ & $101.0 \pm 0.3$ & $45.7 \pm 2.4$ & $72.3 \pm 0.6$ \\
\hline 200 & - & - & $48.6 \pm 0.7$ & $74.2 \pm 0.6$ \\
\hline 250 & $72.4 \pm 0.6$ & $41.1 \pm 0.2$ & $99.7 \pm 5.7$ & $43.5 \pm 1.3$ \\
\hline \multicolumn{5}{|c|}{ NNK (ng/g) } \\
\hline 23 & $270.1 \pm 1.5$ & $270.1 \pm 1.5$ & $225.3 \pm 4.9$ & $225.3 \pm 4.9$ \\
\hline 23 & $296.1 \pm 2.4$ & $296.1 \pm 2.4$ & $218.0 \pm 1.7$ & $218.0 \pm 1.7$ \\
\hline 23 & - & - & $239.0 \pm 1.4$ & $239.0 \pm 1.4$ \\
\hline 100 & $318.5 \pm 7.4$ & $314.5 \pm 1.9$ & $242.8 \pm 5.7$ & $235.0 \pm 1.5$ \\
\hline 100 & - & - & $236.2 \pm 8.1$ & $225.6 \pm 3.3$ \\
\hline 150 & $341.0 \pm 1.33$ & $343.9 \pm 3.9$ & $240.6 \pm 5.5$ & $225.4 \pm 0.1$ \\
\hline 150 & - & - & $231.4 \pm 0.1$ & - \\
\hline 200 & $352.7 \pm 4.3$ & $658.7 \pm 9.4$ & $249.1 \pm 4.9$ & $349.1 \pm 6.8$ \\
\hline 200 & - & - & $259.0 \pm 0.2$ & $340.3 \pm 0.4$ \\
\hline 250 & $640.0 \pm 13.1$ & $269.7 \pm 0.5$ & $430.6 \pm 32.1$ & $216.4 \pm 2.7$ \\
\hline
\end{tabular}

\subsection{TSNA levels in the heated tobaccos}

The experimental results for levels of TSNAs in the six evaluated tobaccos for the two heating intervals $(2 \mathrm{~min}$ and $5 \mathrm{~min}$ ) are indicated in Tables 8 to 10 . In these tables, the listed and repeated temperatures (for a specific TSNA in each tobacco) indicate results from repeated whole experi- ments (including heating of the tobacco and LC/MS/MS measurement).

Each LC/MS/MS measurement for every experiment was performed in duplicate and the RSD\% values are reported between repeated LC/MS/MS measurements.

The results of TSNA levels in heated flue-cured tobaccos FC-Lo and FC-Up are indicated in Table 8. 
Table 9. Variation of TSNAs in lower stalk Burley tobaccos upon heating (in $\mathbf{n g} / \mathbf{g}$ ).

\begin{tabular}{|c|c|c|c|c|}
\hline \multirow{2}{*}{$\begin{array}{c}\text { Temperature } \\
\left({ }^{\circ} \mathrm{C}\right)\end{array}$} & \multicolumn{2}{|c|}{ Burley lower stalk, Bu-Lo } & \multicolumn{2}{|c|}{ Burley upper stalk, Bu-Up } \\
\hline & $2 \min$ & $5 \min$ & $2 \min$ & $5 \min$ \\
\hline \multicolumn{5}{|c|}{ NNN (ng/g) } \\
\hline 23 & $4678.4 \pm 262.0$ & $4678.4 \pm 262.0$ & $4666.7 \pm 65.8$ & $4666.7 \pm 65.8$ \\
\hline 23 & $4698.2 \pm 40.4$ & $4698.2 \pm 40.4$ & $4893.9 \pm 15.2$ & $4893.9 \pm 15.2$ \\
\hline 100 & $4715.8 \pm 98.1$ & $4701.7 \pm 44.7$ & $5458.9 \pm 21.3$ & $5753.9 \pm 51.8$ \\
\hline 150 & $4903.5 \pm 219.2$ & $5968.8 \pm 69.2$ & $6288.3 \pm 4.4$ & $7508.4 \pm 7.5$ \\
\hline 200 & $5930.8 \pm 215.3$ & $8541.1 \pm 160.6$ & $6953.1 \pm 47.3$ & $10030.8 \pm 68.2$ \\
\hline 200 & - & - & $6947 \pm 42.4$ & - \\
\hline \multirow[t]{2}{*}{250} & $8961.2 \pm 49.3$ & $9383.9 \pm 122.0$ & $8525.8 \pm 148.3$ & $7077.4 \pm 38.9$ \\
\hline & \multicolumn{4}{|c|}{ NAT $(n g / g)$} \\
\hline 23 & $4611 \pm 29.5$ & $4611 \pm 29.5$ & $4430.1 \pm 28.8$ & $4430.1 \pm 28.8$ \\
\hline 23 & $4622.5 \pm 268.1$ & $4622.5 \pm 268.1$ & $4894.2 \pm 5.4$ & $4894.2 \pm 5.4$ \\
\hline 100 & $4627.4 \pm 5.1$ & $4660.9 \pm 7.9$ & $5585.9 \pm 6.1$ & $5893.8 \pm 86.0$ \\
\hline 150 & $4812.6 \pm 169.9$ & $6485.5 \pm 81.7$ & $6386.6 \pm 44.1$ & $8067.5 \pm 49.2$ \\
\hline 200 & $6327.2 \pm 160.1$ & $10063.8 \pm 169.1$ & $10005.5 \pm 0.0$ & $10677.6 \pm 59.8$ \\
\hline 200 & - & - & $9543.5 \pm 40.1$ & - \\
\hline \multirow[t]{2}{*}{250} & $10655.9 \pm 86.3$ & $4775.7 \pm 27.2$ & $8994.5 \pm 161.9$ & $1356.7 \pm 3.7$ \\
\hline & \multicolumn{4}{|c|}{ NAB (ng/g) } \\
\hline 23 & $204.7 \pm 10.8$ & $204.7 \pm 10.8$ & $176.4 \pm 2.1$ & $176.4 \pm 2.1$ \\
\hline 23 & $194.8 \pm 0.8$ & $194.8 \pm 0.8$ & $190.1 \pm 0.8$ & $190.1 \pm 0.8$ \\
\hline 100 & $199.2 \pm 1.4$ & $196.0 \pm 1.2$ & $223.8 \pm 0.1$ & $224.5 \pm 1.7$ \\
\hline 150 & $207.6 \pm 9.3$ & $290.2 \pm 1.6$ & $249.1 \pm 2.7$ & $340.8 \pm 0.5$ \\
\hline 200 & $282.6 \pm 7.1$ & $629.9 \pm 7.1$ & $423.4 \pm 2.4$ & $582.1 \pm 2.9$ \\
\hline 200 & - & - & $396.8 \pm 3.1$ & - \\
\hline \multirow[t]{2}{*}{250} & $637.3 \pm 2.5$ & $1683.8 \pm 11.1$ & $474.9 \pm 6.5$ & $1734.9 \pm 15.4$ \\
\hline & \multicolumn{4}{|c|}{ NNK (ng/g) } \\
\hline 23 & $855.6 \pm 32.3$ & $855.6 \pm 32.3$ & $791.7 \pm 1.7$ & $791.7 \pm 1.7$ \\
\hline 23 & $866.4 \pm 0.4$ & $866.4 \pm 0.4$ & $754.8 \pm 0.0$ & $754.8 \pm 0.0$ \\
\hline 100 & $844.9 \pm 9.5$ & $866.9 \pm 6.7$ & $858.8 \pm 13.7$ & $884.9 \pm 1.8$ \\
\hline 150 & $898.8 \pm 29.3$ & $1039.6 \pm 11.1$ & $963.6 \pm 3.1$ & $1145.3 \pm 1.3$ \\
\hline 200 & $1040.9 \pm 38.6$ & $2551.8 \pm 14.5$ & $1298.4 \pm 2.9$ & $2065.1 \pm 14.2$ \\
\hline 200 & - & - & $1216.6 \pm 13.5$ & - \\
\hline 250 & $3517.8 \pm 1.8$ & $4749 \pm 2.4$ & $1711.0 \pm 27.5$ & $2916.5 \pm 3.8$ \\
\hline
\end{tabular}

The results of TSNA levels in heated Burley tobaccos BuLo and Bu-Up are indicated in Table 9. The results of TSNA levels in heated Oriental tobaccos are indicated in Table 10.

\section{DISCUSSION}

A typical level variation of TSNAs with oven temperatures as described in Tables 8 to 10 , is shown in Figure 4 for NNN in FC-Up samples for 2-min heating intervals, and for 5-min heating intervals in Figure 5.

For other types of tobacco and other TSNAs it was common to obtain similar curves of variations although there were also some exceptions when the drop of the TSNA level for 5-min heating at $250{ }^{\circ} \mathrm{C}$ was less obvious. This can be explained by possible non-homogeneities in the heating of the specific sample. The typical increase in TSNA levels described in Tables 8 to 10 can be visualized by comparing Figure 6, which shows the initial TSNA levels with Figure 7, which shows the levels after 2-min heating at $200{ }^{\circ} \mathrm{C}$.

Also, as expected, the heating of tobacco for $5 \mathrm{~min}$ led to increased formation of TSNAs, as shown by comparing the results illustrated in Figure 7 with those illustrated in Figure 8 for heating at $200{ }^{\circ} \mathrm{C}$ for $5 \mathrm{~min}$ (all data taken from Tables 8 to 10$)$.

The heating of tobacco for $2 \mathrm{~min}$ at $250{ }^{\circ} \mathrm{C}$ continues in most cases to increase the TSNA level, as is illustrated by comparing Figure 7 with the data from Figure 9 which shows the results for heating the tobaccos for $2 \mathrm{~min}$ at $250^{\circ} \mathrm{C}$. However, by further heating the tobacco for $5 \mathrm{~min}$ at $250{ }^{\circ} \mathrm{C}$, the levels of TSNAs were decreasing in most cases, as can be seen by comparing the results from Figure 9 with those from Figure 10 which shows the results for heating the samples for $5 \mathrm{~min}$ at $250{ }^{\circ} \mathrm{C}$.

The results of this study indicate that moderate temperatures and extended heating time are factors leading to an 
Table 10. Variation of TSNAs in Oriental tobaccos upon heating (in $\mathbf{n g} / \mathbf{g}$ ).

\begin{tabular}{|c|c|c|c|c|}
\hline \multirow{2}{*}{$\begin{array}{l}\text { Temperature } \\
\left({ }^{\circ} \mathrm{C}\right)\end{array}$} & \multicolumn{2}{|c|}{ Oriental (1), Or(1) } & \multicolumn{2}{|c|}{ Oriental (2), Or(2) } \\
\hline & $2 \min$ & $5 \mathrm{~min}$ & $2 \min$ & $5 \mathrm{~min}$ \\
\hline \multicolumn{5}{|c|}{ NNN (ng/g) } \\
\hline 23 & $156.9 \pm 1.3$ & $156.9 \pm 1.3$ & $130.2 \pm 0.5$ & $130.2 \pm 0.5$ \\
\hline 23 & $156.3 \pm 1.3$ & $156.3 \pm 1.3$ & $127.0 \pm 0.3$ & $127.0 \pm 0.3$ \\
\hline 23 & - & - & $122.0 \pm 2.7$ & $122.0 \pm 2.7$ \\
\hline 100 & $203.7 \pm 1.9$ & $218.0 \pm 1.8$ & $146.2 \pm 0.1$ & $147.6 \pm 1.5$ \\
\hline 150 & $211.4 \pm 1.6$ & $273.4 \pm 1.5$ & $194.1 \pm 0.2$ & $225.3 \pm 1.5$ \\
\hline 200 & $282.1 \pm 3.4$ & $489.2 \pm 13.0$ & $205 \pm 0.8$ & $325.3 \pm 2.6$ \\
\hline 200 & $307.0 \pm 1.0$ & - & - & $319.5 \pm 5.8$ \\
\hline 250 & $386.7 \pm 11.5$ & $146.2 \pm 1.0$ & $289.1 \pm 5.2$ & - \\
\hline 250 & - & - & $298.3 \pm 0.5$ & - \\
\hline \multicolumn{5}{|c|}{ NAT (ng/g) } \\
\hline 23 & $55.0 \pm 0.9$ & $55.0 \pm 0.9$ & $33.3 \pm 0.1$ & $33.3 \pm 0.1$ \\
\hline 23 & $54.6 \pm 0.7$ & $54.6 \pm 0.7$ & $33.8 \pm 1.3$ & $33.8 \pm 1.3$ \\
\hline 100 & $69.7 \pm 0.4$ & $77.7 \pm 1.2$ & $39.0 \pm 1.0$ & $39.1 \pm 0.7$ \\
\hline 150 & $73.2 \pm 1.5$ & $122.1 \pm 0.2$ & $53.5 \pm 0.8$ & $67.7 \pm 2.0$ \\
\hline 200 & $130.8 \pm 1.5$ & $284.4 \pm 4.5$ & $64.7 \pm 1.0$ & $121.7 \pm 2.1$ \\
\hline 200 & $139.3 \pm 0.9$ & - & - & $118.6 \pm 0.5$ \\
\hline 250 & $207.3 \pm 3.8$ & $12.9 \pm 0.4$ & $105.6 \pm 2.7$ & - \\
\hline 250 & - & - & $108.8 \pm 1.7$ & - \\
\hline \multicolumn{5}{|c|}{ NAB (ng/g) } \\
\hline 23 & $6.2 \pm 0.3$ & $6.2 \pm 0.3$ & $4.9 \pm 0.1$ & $4.9 \pm 0.1$ \\
\hline 23 & $6.1 \pm 0.3$ & $6.1 \pm 0.3$ & $4.7 \pm 0.1$ & $4.7 \pm 0.1$ \\
\hline 100 & $6.7 \pm 0.3$ & $7.1 \pm 0.6$ & $4.8 \pm 0.1$ & $5.1 \pm 0.0$ \\
\hline 150 & $6.9 \pm 0.5$ & $10.3 \pm 0.1$ & $5.7 \pm 0.3$ & $6.7 \pm 0.0$ \\
\hline 200 & $10.3 \pm 0.2$ & $28.0 \pm 0.2$ & $7.0 \pm 0.0$ & $18.1 \pm 0.4$ \\
\hline 200 & $11.2 \pm 0.4$ & - & - & $17.6 \pm 0.0$ \\
\hline 250 & $18.4 \pm 0.4$ & $25.6 \pm 0.1$ & $13.9 \pm 0.7$ & - \\
\hline 250 & - & - & $15.3 \pm 0.1$ & - \\
\hline \multicolumn{5}{|c|}{ NNK (ng/g) } \\
\hline 23 & $41.3 \pm 0.6$ & $41.3 \pm 0.6$ & $32.9 \pm 0.4$ & $32.9 \pm 0.4$ \\
\hline 23 & $44.7 \pm 1.2$ & $44.7 \pm 1.2$ & $32.4 \pm 0.4$ & $32.4 \pm 0.4$ \\
\hline 100 & $54.2 \pm 0.8$ & $54.7 \pm 0.4$ & $38.2 \pm 2.0$ & $38.2 \pm 0.4$ \\
\hline 150 & $55.2 \pm 1.4$ & $57.5 \pm 0.4$ & $45.2 \pm 0.8$ & $49.0 \pm 1.5$ \\
\hline 200 & $56.8 \pm 2.0$ & $119.8 \pm 0.4$ & $48.4 \pm 0.6$ & $76.8 \pm 0.1$ \\
\hline 200 & $59.8 \pm 0.7$ & - & - & $76.8 \pm 0.3$ \\
\hline 250 & $85.5 \pm 1.4$ & $91.5 \pm 2.8$ & $62.0 \pm 0.3$ & - \\
\hline 250 & - & - & $65.9 \pm 0.2$ & - \\
\hline
\end{tabular}

increase in the TSNA levels in tobacco. They also show that this increase takes place up to a point as the temperature increases, and beyond this point, very likely, some TSNA's decomposition starts to take place. In order to keep the TSNA levels as low as possible, unnecessary heating of tobacco at moderate temperatures must be avoided. However, tobacco heating cannot be avoided in many devices such as for example in the heat-not-burn type cigarettes, where certain temperatures are a precondition for the release of flavors and nicotine as well as humectants added to tobacco. As a result, the increase in TSNAs cannot be avoided. By selecting specific tobaccos already low in TSNAs, an excessive increase of TSNAs due to heating can be diminished. The decomposition of TSNAs that occurs when tobacco is heated beyond a specific temperature and length of time could probably be used for lowering the TSNA levels. Nevertheless a careful evaluation of this process must be performed with additional examination and control of the decomposition of other tobacco constituents such as sugars.

\section{CONCLUSIONS}

Six commonly used tobaccos, including two flue-cured, two Burleys and two Oriental tobaccos were analyzed for their TSNA levels. These tobaccos were heated in sealed glass containers at oven temperatures of $100,150,200$ and $250{ }^{\circ} \mathrm{C}$ 
NNN FC-Up 2 min

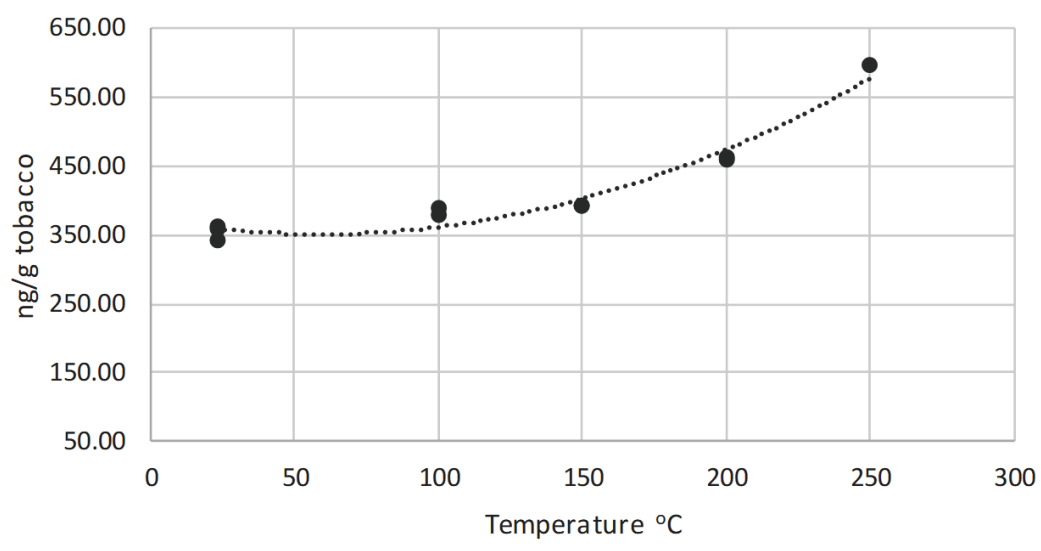

Figure 4. Variation of NNN in FC-Up sample with 2 min heating at different oven temperatures.

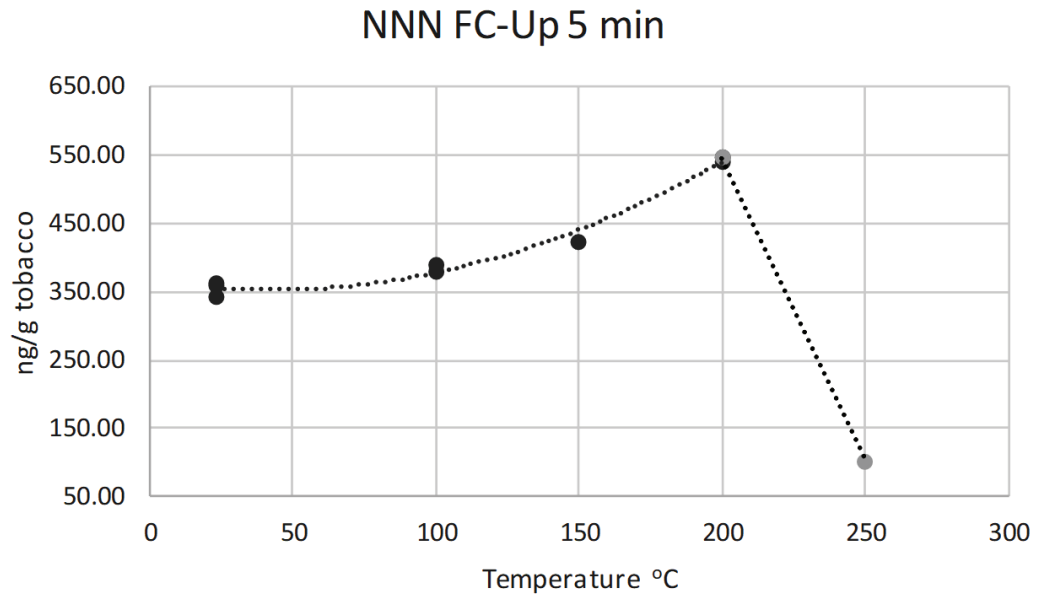

Figure 5. Variation of NNN in FC-Up sample with 5 min heating at different oven temperatures.

Initial TSNAs levels

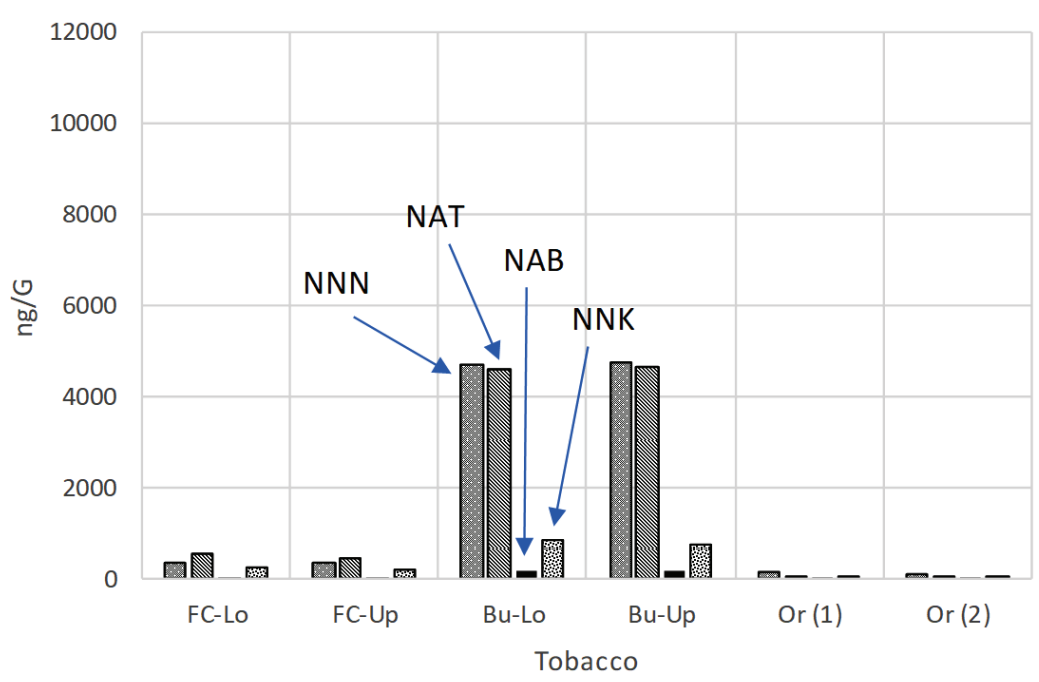

Figure 6. Initial levels of TSNAs (data taken from Table 7). 
TSNAs levels at $200{ }^{\circ} \mathrm{C}$ for 2 min

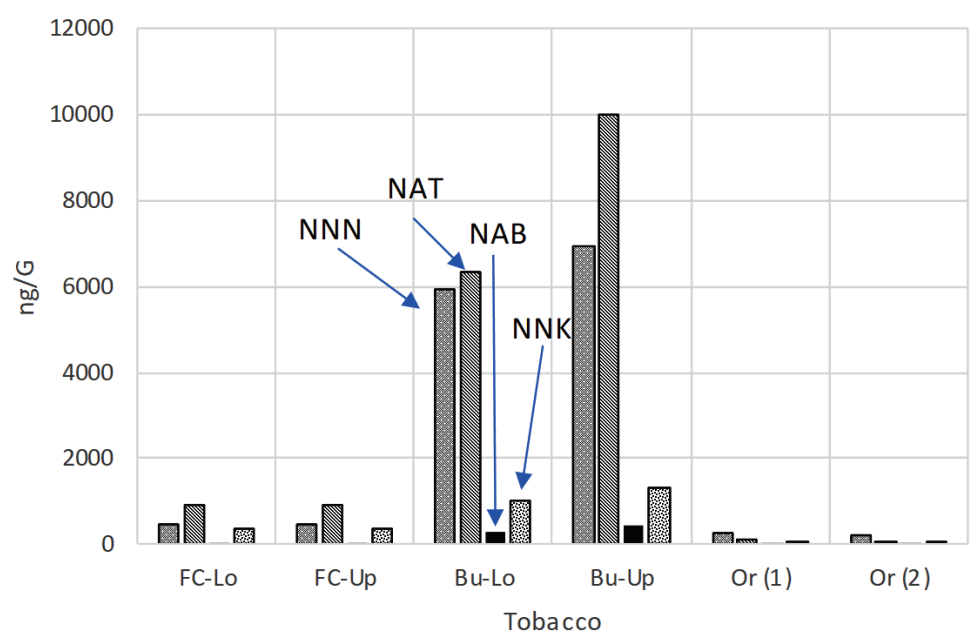

Figure 7. Levels of TSNAs after heating for $2 \mathrm{~min}$ at $200^{\circ} \mathrm{C}$ (data taken from Tables 8 to 10).

TSNAs levels at $200^{\circ} \mathrm{C}$ for 5 min

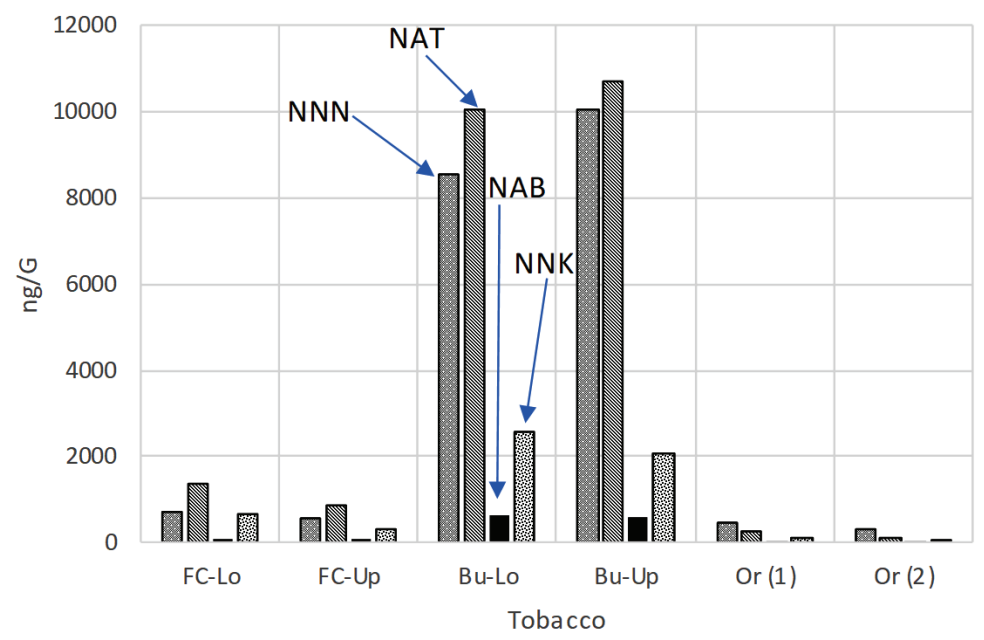

Figure 8. Levels of TSNAs after heating for $5 \mathrm{~min}$ at $200^{\circ} \mathrm{C}$ (data taken from Tables 8 to 10).

TSNAs levels at $250^{\circ} \mathrm{C}$ for 2 min

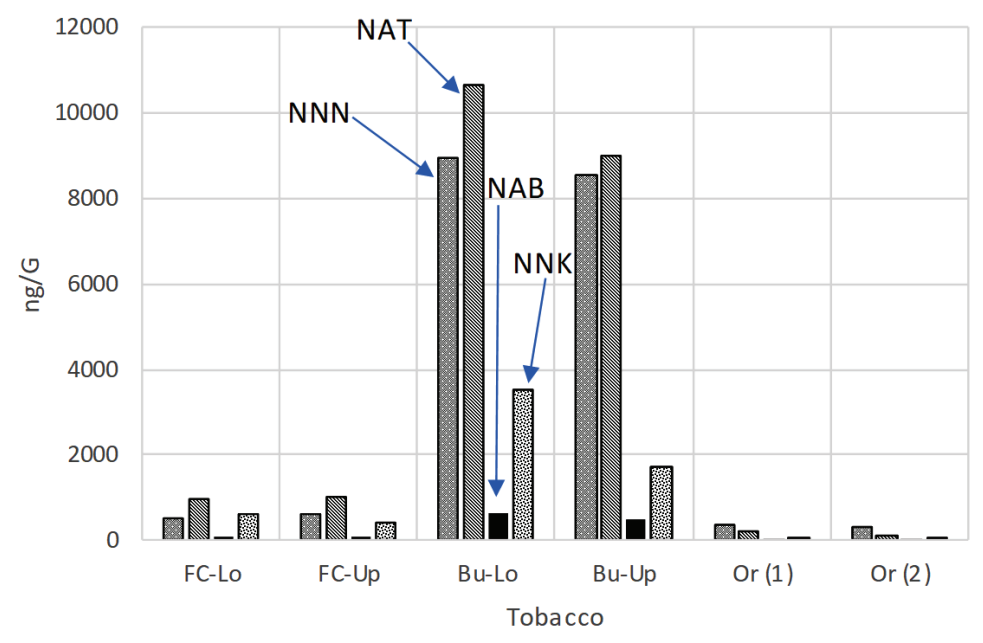

Figure 9. Levels of TSNAs after heating for $2 \mathrm{~min}$ at $250^{\circ} \mathrm{C}$ (data taken from Tables 8 to 10). 


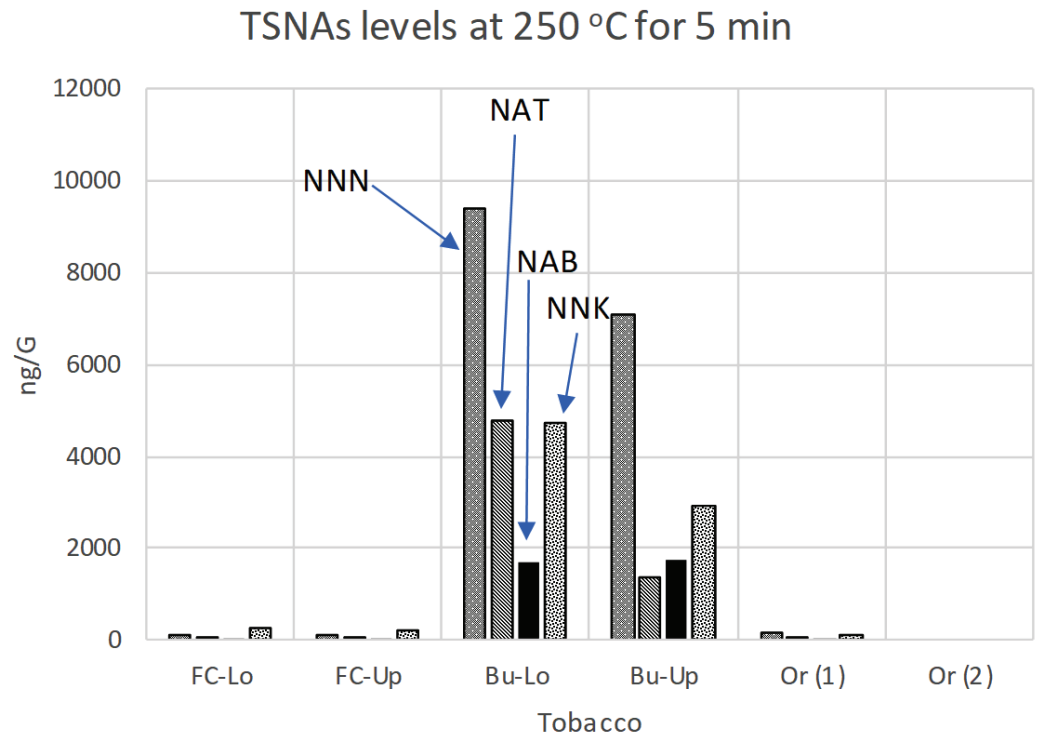

Figure 10. Levels of TSNAs after heating for $5 \mathrm{~min}$ at $250^{\circ} \mathrm{C}$ (data taken from Tables 8 to 10).

for intervals of $2 \mathrm{~min}$ or $5 \mathrm{~min}$. The TSNA levels were found to increase up to a point during tobacco heating, reaching levels as high as double from the initial level. However, the TSNAs increase did not continue when further heating was performed due to some TSNA's decomposition probably taking place beyond a specific point of heating.

\section{REFERENCES}

1. U.S. Food \& Drug Administration (FDA): Reporting Harmful and Potentially Harmful Constituents in Tobacco Products and Tobacco Smoke Under Section 904(a)(3) of the Federal Food, Drug, and Cosmetic Act; Issued by Center for Tobacco Products, Docket Number: FDA-2012-D-0049-0002, April 2012. Available at: https://www.fda.gov/TobaccoProducts/Labeling/Rules RegulationsGuidance/ucm297752.htm (accessed July 2020).

2. International Agency for Research on Cancer (IARC): Agents Classified by the IARC Monographs, Volumes 1-127; IARC, Lyon, France. Available at: https://monographs.iarc.fr/agents-classified-by-the-iarc/ (accessed July 2020).

3. Foster, M., C. Liu, M.G. Duke, K.G. McAdam, and C.J. Proctor: An Experimental Method to Study Emissions From Heated Tobacco Between 100-200 ${ }^{\circ} \mathrm{C}$; Chem. Cent. J. 9 (2015) 20-30.

DOI: 10.1186/s13065-015-0096-1

4. Uchiyama, S., M. Noguchi, N. Takagi, H. Hayashida, Y. Inaba, H. Ogura, and N. Kunugita: Simple Determination of Gaseous and Particulate Compounds Generated From Heated Tobacco Products; Chem. Res. Toxicol. 31 (2018) 585-593.

DOI: $10.1021 /$ acs.chemrestox.8b00024

5. Djordjevic, M.V., J. Fan, L.P. Bush, K.D. Brunnemann, and D. Hoffmann: Effect of Storage Conditions on Levels of Tobacco Specific N-Nitrosamines and N-Nitrosamino
Acids in U.S. Moist Snuff; J. Agric. Food. Chem. 41 (1993) 1790-1794. DOI: 10.1021/jf00034a051

6. Stepanov, I., S.G. Carmella, S.S. Hecht, and G. Duca: Analysis of Tobacco-Specific Nitrosamines in Moldovan Cigarette Tobacco; J. Agric. Food Chem. 50 (2002) 2793-2797. DOI: 10.1021/jf011552j

7. Wu, W., D.L. Ashley, and C.H. Watson: Simultaneous Determination of Five Tobacco-Specific Nitrosamines in Mainstream Cigarette Smoke by Isotope Dilution Liquid Chromatography/Electrospray Ionization Tandem Mass Spectrometry; Anal. Chem. 75 (2003) 4827-4832. DOI: 10.1021/ac030135y

8. Jansson, C., A. Paccou, and B.G. Oesterdahl: Analysis of Tobacco-Specific N-Nitrosamines in Snuff by Ethyl Acetate Extraction and Liquid Chromatography-Tandem Mass Spectrometry; J. Chromatogr. A 1008 (2003) 135-143. DOI: 10.1016/S0021-9673(03)00981-6

9. Oesterdahl, B.G., C. Jansson, and A. Paccou: Decreased Levels of Tobacco-Specific N-Nitrosamines in Moist Snuff on the Swedish Market; J. Agric. Food Chem. 52 (2004) 5085-5088. DOI: 10.1021/jf049931a.

10. Wagner, K.A., N.H. Finkel, J.E. Fossett, and I.G. Gillman: Development of a Quantitative Method for the Analysis of Tobacco-Specific Nitrosamines in Mainstream Cigarette Smoke Using Isotope Dilution Liquid Chromatography/Electrospray Ionization Tandem Mass Spectrometry; Anal. Chem. 77 (2005) 1001-1006. DOI: $10.1021 / \mathrm{ac} 048887 \mathrm{v}$

11. Stepanov, I., J. Jensen, D. Hatsukami, and S.S. Hecht: Tobacco-Specific Nitrosamines in New Tobacco Products; Nicotine Tob. Res. 8 (2006) 309-313. DOI: 10.1080/14622200500490151

12. Wu, J., P. Joza, M. Sharifi, W.S. Rickert, and J.H. Lauterbach: Quantitative Method for the Analysis of Tobacco-Specific Nitrosamines in Cigarette Tobacco and Mainstream Cigarette Smoke by Use of Isotope Dilution Liquid Chromatography Tandem Mass Spectrometry; Anal. Chem. 80 (2008) 1341-1345. DOI: $10.1021 / \mathrm{ac} 702100 \mathrm{c}$ 
13. Moldoveanu, S.C. and M. Borgerding: Formation of Tobacco Specific Nitrosamines in Mainstream Cigarette Smoke; Part 1, FTC Smoking; Beitr. Tabakforsch. Int. 23 (2008) 19-31. DOI: 10.2478/cttr-2013-0845

14. Sleiman, M., R.L. Maddalena, L.A. Gundel, and H. Destaillats: Rapid and Sensitive Gas ChromatographyIon-Trap Tandem Mass Spectrometry Method for the Determination of Tobacco-Specific N-Nitrosamines in Secondhand Smoke; J. Chromatogr. A 1216 (2009) 7899-7905. DOI: 10.1016/j.chroma.2009.09.020

15. Xiong, W., H. Hou, X. Jiang, G. Tang, and Q. Hu: Simultaneous Determination of Four Tobacco-Specific N-Nitrosamines in Mainstream Smoke for Chinese Virginia Cigarettes by Liquid Chromatography-Tandem Mass Spectrometry and Validation Under ISO and "Canadian Intense" Machine Smoking Regimes; Anal. Chim. Acta 674 (2010) 71-78.

DOI: $10.1016 /$ j.aca.2010.06.011

16. Kim, H.-J. and H.-S. Shin: Determination of TobaccoSpecific Nitrosamines in Replacement Liquids of Electronic Cigarettes by Liquid ChromatographyTandem Mass Spectrometry; J. Chromatogr. A 1291 (2013) 48-55. DOI: 10.1016/j.chroma.2013.03.035

17. Zhang, J., R. Bai, X. Yi, Z. Yang, X. Liu, J. Zhou, and W. Liang: Fully Automated Analysis of Four TobaccoSpecific N-Nitrosamines in Mainstream Cigarette Smoke Using Two-Dimensional Online Solid Phase Extraction Combined with Liquid ChromatographyTandem Mass Spectrometry; Talanta 146 (2016) 216-224. DOI: 10.1016/j.talanta.2015.08.057

18. Moldoveanu, S.C., J. Zhu, and N. Qian: Analysis of Traces of Tobacco-Specific Nitrosamines (TSNAs) in USP Grade Nicotine, E-Liquids, and Particulate Phase Generated by the Electronic Smoking Devices; Beitr. Tabakforsch Int. 27 (2017) 86-97.

DOI: $10.1515 /$ cttr-2017-0009

Correspondig author:

Serban C. Moldoveanu

R.J. Reynolds Tobacco Co.

950 Reynolds Blvd.

Winston-Salem NC 27105, USA

E-mail:moldovs@rjrt.com 